\title{
DADOS - Revista de Ciências Sociais
}

versão On-line ISSN 1678-4588

DADOS vol. 59 n 1 Rio de Janeiro jan./mar. 2016

http:/ /dx.doi.org/10.1590/0011525820160001

ERRATA

\section{Errata}

No artigo "Desigualdades de gênero na carreira acadêmica no Brasil", com número de DOI: 10.1590/00115258201558, publicado na DADOS - Revista de Ciências Sociais, 2015; 58(3):749-789 - Moschkovich, M, Almeida AM, idioma português, nas páginas 749 e 755, onde se lê:

\section{p. 749:}

O número de mulheres com título de doutorado vem crescendo de maneira constante ao longo das últimas décadas no Brasil, tendo chegado a 51,5\% do total de doutores titulados em 2008 (CGEE, 2010:101). A proporção de professoras no ensino superior também cresceu, chegando a 55\% do total de docentes em 2009 (Inep, 2011). Trata-se de uma mudança social significativa, principalmente em se tratando de um país onde, à semelhança de outros, trabalhadores do sexo masculino são tradicionalmente maioria nos postos mais prestigiosos e mais bem remunerados do mercado de trabalho (Bruschini, 2007; Bruschini e Puppin, 2004). Importa, por isso, verificar o alcance e as implicações da ampliação da presença feminina nas carreiras científicas e no ensino superior. Particularmente, interessa examinar se a maior igualdade de acesso ao doutorado e o aumento do número de professoras terão se traduzido numa maior igualdade de acesso às mais altas posições da carreira docente no ensino superior, incluindo aí as posições de chefia e/ou a participação em colegiados superiores. 
Leia-se:

O número de mulheres com título de doutorado vem crescendo de maneira constante ao longo das últimas décadas no Brasil, tendo chegado a 51,5\% do total de doutores titulados em 2008 CGEE, 2010:101(palmente em se tratando de um país onde, à semelhança de outros, trabalhadores do sexo masculino são tradicionalmente maioria nos postos mais prestigiosos e mais bem remunerados do mercado de trabalho (Bruschini, 2007; Bruschini e Puppin, 2004). Importa, por isso, verificar o alcance e as implicações da ampliação da presença feminina nas carreiras científicas e no ensino superior. Particularmente, interessa examinar se a maior igualdade de acesso ao doutorado e o aumento do número de professoras terão se traduzido numa maior igualdade de acesso às mais altas posições da carreira docente no ensino superior, incluindo aí as posições de chefia e/ou a participação em colegiados superiores.

\section{p. 755 , onde se lê:}

Este artigo discute as diferenças entre professores/pesquisadores de uma universidade pública com forte ênfase em pesquisa, segundo seu sexo. Nesse segmento do espaço universitário, a carreira é pouco feminizada. Profissionais do sexo feminino são $45 \%$ do corpo docente nas universidades públicas, embora sejam 55\% no total do corpo docente do ensino superior (Inep, 2011). Quando contabilizadas apenas as universidades públicas presentes no estado de São Paulo, esse número é menor ainda, cerca de $40 \%$. Nas três universidades estaduais paulistas juntas, as docentes do sexo feminino correspondiam, em 2011, a 38\% do corpo docente e, na Universidade Estadual de Campinas, eram apenas cerca de $35 \%$.

\section{Leia-se:}

Este artigo discute as diferenças entre professores/pesquisadores de uma universidade pública com forte ênfase em pesquisa, segundo seu sexo. Nesse segmento do espaço universitário, a carreira é pouco feminizada. Profissionais do sexo feminino são $45 \%$ do corpo docente nas universidades públicas e $45 \%$ no total do corpo docente do ensino superior (Inep, 2011). Quando contabilizadas apenas as universidades públicas presentes no estado de São Paulo, esse número é menor ainda, cerca de $40 \%$. Nas três universidades estaduais paulistas juntas, as docentes do sexo feminino correspondiam, em 2011, a 38\% do corpo docente e, na Universidade Estadual de Campinas, eram apenas cerca de 35\%. 